\title{
Determination of Some Heavy Metals in Raw Petroleum Wastewater Samples Before and After Passing on Australis Phragmites Plant
}

\author{
Mohamed Ezeldin ${ }^{1,2}$, Sulieman A. G. Nasir ${ }^{1}$, Ali M. Masaad ${ }^{1}$, Nawal M. Suleman ${ }^{3}$ \\ ${ }^{1}$ Department of Chemistry, Faculty of Science and Technology, Omdurman Islamic University, Khartoum, Sudan \\ ${ }^{2}$ Department of Quality Control, Almazaq Factory, South of Khartoum, Sudan \\ ${ }^{3}$ Department of Chemistry, Zilfi Facultyof Education, Majmmah University, Zilfi, Saudi Arabia
}

Email address:

wadalmsna3.com@gmail.com (M. Ezeldin)

\section{To cite this article:}

Mohamed Ezeldin, Sulieman A. G. Nasir, Ali M. Masaad, Nawal M. Suleman. Determination of Some Heavy Metals in Raw Petroleum Wastewater Samples Before and After Passing on Australis Phragmites Plant. American Journal of Environmental Protection.

Vol. 4, No. 6, 2015, pp. 354-357. doi: 10.11648/j.ajep.20150406.22

\begin{abstract}
The main objective of this project was determining of lead, cadmium, nickel and chromium in raw petroleum wastewater (RPWW) samples. The samples were taken before and after passage the RPWW on Australis Phragmites Plant (APP). Atomic absorption spectrophotometer was used to determine the heavy metals in RPWW samples before and after passing, The concentration of lead, cadmium, nickel and chromium before passing on APP was found to be $0.25,0.9,0.52 \&$ $0.012 \mathrm{ppm}$ respectively, but after passing on APP was fond to be $0.123,0.75,0.45 \& 0.01 \mathrm{ppm}$, respectively. The obtained results after passage were found within the range assigned by American Society for Testing and Materials ASTM, except the concentration of nickel.
\end{abstract}

Keywords: Heavy Metals, Petroleum Wastewater, Australis Phragmites Plant

\section{Introduction}

\subsection{Petroleum Wastewater}

Refineries can generate a significant amount of wastewater that has been in contact with hydrocarbons. Wastewater can also include water rejected from boiler feed water pretreatment processes (or generated during regenerations) [1]. Wastewater can also refer to cooling tower blowdown stream, or even once-through cooling water that leaves the refinery. Once-through cooling water typically does not receive any treatment before discharge [2]. Contaminated wastewater is typically sent to either a wastewater treatment plant that is located at the facility, or it can be pretreated and sent to the local publicly owned treatment works or thirdparty treatment facility for further treatment. Water that has not been in direct contact with hydrocarbons or which has only minimal contamination can be a source for reuse, a purge stream is removed from the water purification systems in order to prevent the buildup of contaminants. This purge stream is sent to wastewater treatment and is replaced by fresh makeup water [3].

\subsection{Effect of Heavy Metals}

Heavy metals are individual metals and metal compounds that can impact human health. Eight common heavy metals are discussed in this brief: arsenic, barium, cadmium, chromium, lead, mercury, selenium, and silver. These are all naturally occurring substances which are often present in the environment at low levels. In larger amounts, they can be dangerous. Generally, humans are exposed to these metals by ingestion (drinking or eating) or inhalation (breathing). Working in or living near industrial sites which utilize these metals and their compounds increases environmental risks, as does living near sites where these metals have been improperly disposed. Subsistence lifestyles can also impose higher risks of exposure and health impacts because of hunting and gathering activities [4].

\subsubsection{Lead}

As a result of human activities, such as fossil fuel burning, mining, and manufacturing, lead and lead compounds can be found in all parts of our environment. This includes air, soil, 
and water. Lead is used in many different ways. It is used to produce batteries, ammunition, metal products like solder and pipes, and X-ray shielding devices. Lead is a highly toxic metal and, as a result of related health concerns (see below), its use in several products like gasoline, paints, and pipe solder, has been drastically reduced in recent years. Today, the most common sources of lead exposure in the United States are Lead-based paint and possibly water pipes in older homes, contaminated soil, household dust, drinking water, lead crystal, lead in certain cosmetics and toys, and lead-glazed pottery. Health effects EPA has determined that lead is a probable human carcinogen. Lead can affect every organ and system in the body. Long-term exposure of adults can result in decreased performance in some tests that measure functions of the nervous system; weakness in fingers, wrists, or ankles; small increases in blood pressure; and anemia $[4,5]$.

\subsubsection{Cadmium}

Cadmium is a very toxic metal. All soils and rocks, including coal and mineral fertilizers, contain some cadmium. Cadmium has many uses, including batteries, pigments, metal coatings, and plastics. It is used extensively in electroplating [5].

\subsubsection{Nickel}

Nickel is a very abundant, naturally occurring metal and is used for a variety of industrial purposes. Nickel compounds, such as barium-nickel alloys are used for spark-plug electrodes and in vacuum tubes as a drying and oxygenremoving agent; nickel sulfide is used in fluorescent lamps; nickel sulfate is used in diagnostic medicine; nickel nitrate and chlorate give fire works a green color. Barium compounds are also used in drilling muds, paint, bricks, ceramics, glass, and rubber [4] [5].

\subsubsection{Chromium}

Chromium is found in rocks, animals, plants, and soil and can be a liquid, solid, or gas. Chromium compounds bind to soil and are not likely to migrate to ground water but, they are very persistent in sediments in water. Chromium is used in metal alloys such as stainless steel; protective coatings on metal (electroplating); magnetic tapes; and pigments for paints, cement, paper, rubber, composition floor covering and other materials. Its soluble forms are used in wood preservatives [6].

\section{Materials and Methods}

\subsection{Materials}

All chemicals used were of analytical reagent grade (AR) and of highest purity degree available. They included hydrochloric acid, stock lead (II) solution, stock cadmium (II) solution, stock nickel (II) solution, stock chromium(III) solution, deionized water.

\subsection{Methods}

\section{Preparation of samples}

In clean $100 \mathrm{~mL}$ volumetric flasks about $5 \mathrm{~mL}$ of petroleum raw wastewater samples before and after passing on APP was diluted to the mark by using deionized water. Then the solutions were homogenized well.

Preparation of standard solutions

Standard solutions of lead (II), cadmium (II) and nickel (II) were prepared by concentrations $0.01,0.1$. 0.2. 1 ppm, but standard chromium solutions were prepared by concentrations $0.001,0.002,0.01,0.1 \mathrm{ppm}$ from the stock solutions [7].

\section{Blank of instrument}

Atomic absorption spectrophotometer was adjusted to zero point by using deionized water. Absorption of the standard lead (II), cadmium (II), nickel (II) and chromium (III) solutions were measured and recorded automatically by the instrument. The absorption of RPWW before and after passage was measured and recorded. The concentrations of heavy metals in samples were determined directly [7] by using AAS shown in Fig1.

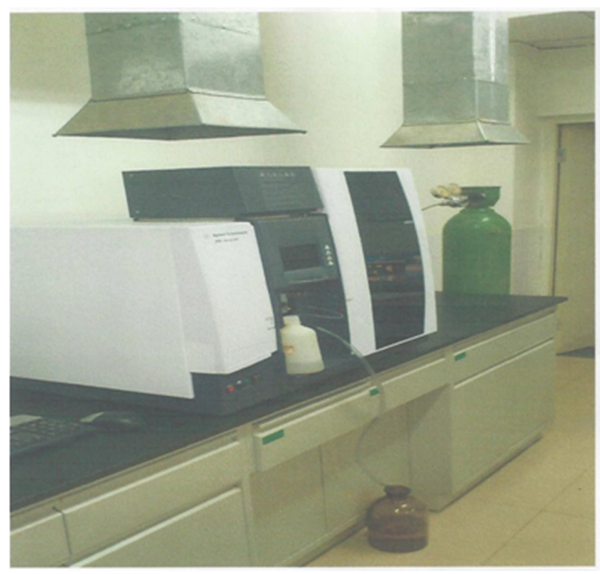

Fig. 1. Atomic Absorption spectroscopy (AAS).

\section{Results and Discussion}

In this project the samples of raw petroleum wastewater before and after passage on Australis Phragmites Plant were taken from Alfola petroleum area, west of Sudan.

The experimental work was conducted at Central Petroleum Laboratories (CPL) ministry of Petroleum, marked heavy metals (lead, cadmium, nickel and chromium) was determined by using Atomic Absorption spectroscopic technique. The obtained results were shown in Table 1.

Table 1. The concentration of marked heavy metals.

\begin{tabular}{lll}
\hline $\begin{array}{l}\text { Heavy } \\
\text { metal }\end{array}$ & $\begin{array}{l}\text { Concentration } \\
\text { (ppm)(before) }\end{array}$ & $\begin{array}{l}\text { Concentration (ppm) } \\
\text { (after) }\end{array}$ \\
\hline Lead & 0.25 & 0.123 \\
Cadmium & 0.9 & 0.75 \\
Nickel & 0.52 & 0.45 \\
Chromium & 0.012 & 0.01 \\
\hline
\end{tabular}

The obtained results represented that: APP showed high ability to sorption the marked heavy metals because the concentration of metals before passing RPWW on the APP higher than concentration after passing that attributed to the 
empty insides of APP.

The concentration of lead, cadmium, nickel and chromium in RPWW after passage on APP was reduced, the reducing process was very important because, lead can affect every organ and system in the body [7], long-term exposure of adults can result in decreased performance in some tests that measure functions of the nervous system; weakness in fingers, wrists, or ankles [8]; small increases in blood pressure; and anemia. Cadmium and cadmium compounds are known human carcinogens. Nickel is not known to cause cancer, short term exposure can cause vomiting, abdominal cramps, diarrhea, difficulties in breathing, increased or decreased blood pressure, numbness around the face, and muscle weakness, large amounts of nickel intake can cause, high blood pressure, changes in heart rhythm or paralysis and possibly death. Chromium compounds are toxins and known human carcinogens, whereas Chromium is an essential nutrient. Breathing high levels can cause irritation to the lining of the nose; nose ulcers; runny nose; and breathing problems, such as asthma, cough, shortness of breath, or wheezing, Skin contact can cause skin ulcers. Allergic reactions consisting of severe redness and swelling of the skin have been noted [8], Long term exposure can cause damage to liver, kidney circulatory and nerve tissues, as well as skin irritation.

ASTM has been assigned right permissible range to heavy metals found in petroleum wastewater, the permissible limits was shown in Table 2 [9].

Table 2. Permissible range of marked heavy metals assigned by ASTM.

\begin{tabular}{ll}
\hline Metals & concentration(ppm) \\
\hline Lead & $<0.2$ \\
Cadmium & $<0.8$ \\
Nickel & $<0.4$ \\
Chromium & $<0.01$ \\
\hline
\end{tabular}

The obtained results before passage on APP out of rang assigned by ASTM, but after passage was found within the range, except the concentration of nickel was found to be 0.45 but the permissible range $<0.4$.

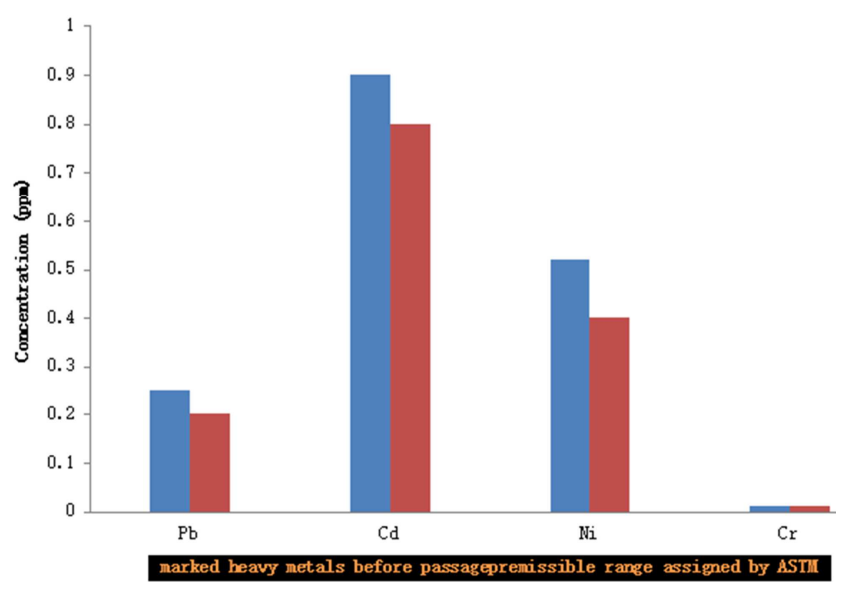

Fig. 2. Comparison between obtained results before passage and a permissible range.

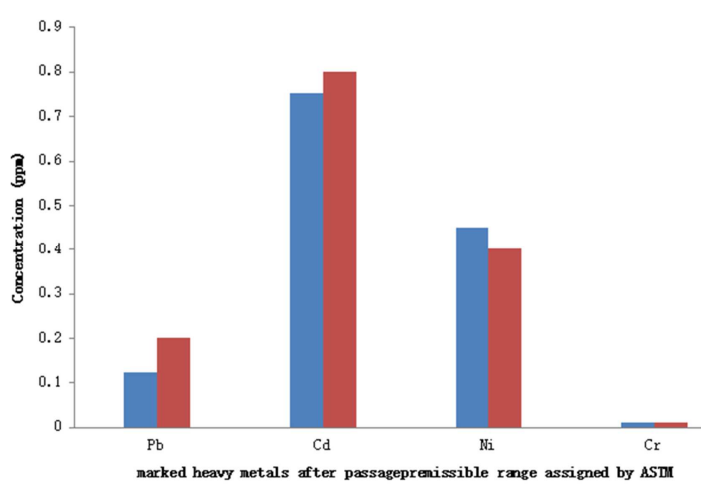

Fig. 3. Comparison between obtained results after passage and a permissible range.

Results of marked heavy metals after passing the RPWW to the APP represented that, the APP showed high ability to sorption because it reduced the marked heavy metals within assigned range except the nickel concentration out of range. The comparison between obtained results before and after passage and permissible range was shown in Fig 2 and Fig 3, respectively.

\section{Conclusion}

Based on the previously discussed analyses, the following conclusions can be summarized as.

- The raw petroleum wastewater samples were taken from Alfola petroleum, field west of Sudan.

- Lead, cadmium, nickel and chromium were determined in raw petroleum wastewater before and after passing on Australis Phragmites Plant, by using atomic absorption spectroscopic technique.

- Australis Phragmites Plant used to reduce the toxicity of raw petroleum wastewater.

- The concentration of marked heavy metals before passage was found out of range assigned by ASTM, on the other hand, the concentrations after passage within the right permissible limits except the concentration of nickel out of range.

\section{Acknowledgement}

Above all, praise is to $G O D$ who has sustained me throughout this work. We would like to express my special thanks to prof. Hatel H. Alkamali, Dean of faculty of science and technology, Omdurman Islamic university. Special thanks also expressed to prof. Mohamed hamaad, Mr. Omar Abdalhameed Goda, Mr. Alsiddig Osama, Mr. Ahmed Mohamed Osman, and all staff at water and environment laboratories in Khartoum.

\section{References}

[1] American Petroleum Institute. (March 1996). A Guide to Leak Detection for Above-Ground Storage Tanks (first addition), USA: Publication 334. 
[2] American Petroleum Institute. (June 2007). Welded Tanks for Oil Storage (11th ed), USA: Downstream Segment, API Standard 650.

[3] Wang \& Howard. (2004)Handbook of Industrial and Hazardous Wastes Treatment (4th ed), USA.

[4] Jha, S, K., Krishnamoorthy, T, M., Pandit, G, G., Nambi, K, S, V. (1999). History of accumulation of mercury and nickel in Thane Creek, Mumbai, using $210 \mathrm{~Pb}$ dating technique. Science of the total environment, 236(1): 91-99.

[5] Lokhande, R, S., Kelkar, N. (1999).Studies on heavy metals in water of Vasai Creek, Maharashtra. Indian J. En-viron. Protect, 19(9): 664-668.

[6] Czepiel, P., Crill, P., Harriss, R. (1995). Nitrous oxide emissions from domestic wastewater treatment. Environmental Science and Technology, 29(9): 2352-2356.
[7] Doorn, M, R, J., Strait, R., Barnard, W., Eklund, B. (1997). Estimate of Global Greenhouse Gas Emissions from Industrial and Domestic Wastewater Treatment, Final Report. Prepared for United States Environmental Protection Agency, Research Triangle Park, NC, USA.

[8] Doorn, M, R, J., Liles, D. (1999). Global Methane, Quantification of Methane Emissions and Discussion of Nitrous Oxide, and Ammonia Emissions from Septic Tanks. Latrines, and Stagnant Open Sewers in the World. Prepared for U.S. EPA, Research Triangle Park, NC, USA.

[9] Annual book of ASTM standards. (2005). American Society for Testing and Materials. West Conshohocken: Salvter. J. Rand. 